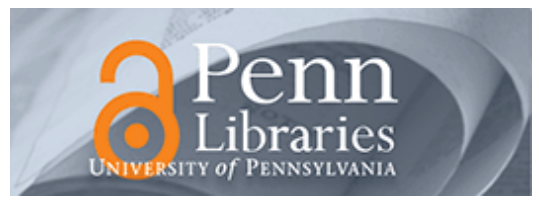

University of Pennsylvania ScholarlyCommons

\title{
The Relationship Between Family Responsibilities and Employment Status Among College and University Faculty
}

Laura W. Perna

University of Pennsylvania, Iperna@gse.upenn.edu

Follow this and additional works at: https://repository.upenn.edu/gse_pubs

Part of the Higher Education Commons, and the Social and Cultural Anthropology Commons

\section{Recommended Citation}

Perna, L. W. (2001). The Relationship Between Family Responsibilities and Employment Status Among College and University Faculty. The Journal of Higher Education, 72 (5), 584-611. http://dx.doi.org/ $10.2307 / 2672882$

This paper is posted at ScholarlyCommons. https://repository.upenn.edu/gse_pubs/367

For more information, please contact repository@pobox.upenn.edu. 


\title{
The Relationship Between Family Responsibilities and Employment Status Among College and University Faculty
}

\author{
Abstract \\ This study uses data from the 1993 National Study of Post-secondary Faculty to examine the extent to \\ which the concentration of women among part-time and nontenure-track faculty is related to family \\ responsibilities. Descriptive and multinomial logistic regression analyses are used to examine the \\ research questions. \\ Disciplines \\ Education | Higher Education | Social and Cultural Anthropology
}


The Relationship Between Family

Responsibilities and Employment Status Among College and University Faculty

Although the participation of mothers in the labor force is viewed more favorably now than in the past, a substantial proportion of American workers continue to believe that women should focus their efforts on the home (Bond, Galinsky, \& Swanberg, 1997). For example, surveys by the Families and Work Institute revealed that $41 \%$ of employees nationwide agreed in 1997 that men should be the breadwinner and women should care for the home and children, down from 64\% in 1977 (Bond, Galinsky, \& Swanberg, 1997).

Research suggests that college and university faculty also perceive tension between work and family roles (Cole \& Zuckerman, 1987; Finkel, Olswang, \& She, 1994; Marshall \& Jones, 1990; Sorcinelli \& Near, 1989). For instance, from their exploratory study of 12 women and minorities who had made choices about entering academia, Bronstein, Rothblum, and Solomon (1993) concluded that the concentration of women in nontenure-track and part-time positions was due, in part, to the conflict between career and family demands. Through interviews, Cole and Zuckerman (1987) found that even the youngest women scientists in their sample, women who had received their doctorates during the 1970s, encountered individuals who viewed marriage and motherhood to be incompatible with a scientific career. Although Marshall and Jones (1990) found that the timing of childbearing was unrelated to salaries and academic rank among female higher education deans, ad-

The author is grateful for the comments and suggestions of Jeffrey Milem and three anonymous reviewers.

Laura W. Perna is assistant professor, Department of Education Policy and Leadership, University of Maryland at College Park.

The Journal of Higher Education, Vol. 72, No. 5 (September/October 2001)

Copyright (C) 2001 by The Ohio State University 
ministrators, and counselors, they also found that about two-thirds of their sample believed that childbearing had negatively affected their careers, particularly in terms of their professional advancement and mobility. A survey of tenured and tenure-track faculty at one university showed that the majority ( $70 \%$ ) believed that taking leave after the birth of a child would be detrimental to their careers (Finkel et al., 1994).

The lower representation of married women than single women, and women with children than childless women, among the nation's college and university faculty may also suggest the difficulties associated with fulfilling both family and career responsibilities. Analyses of the 1993 National Study of Postsecondary Faculty (NSOPF:93) reveal that women represent a smaller share of married than never married faculty ( $34 \%$ versus $52 \%$ ) and a smaller share of faculty with children than childless faculty (31\% versus 54\%). Some research (e.g., Cooney \& Uhlenberg, 1989) suggests that these patterns are similar to those for other professional women. For example, using 1980 census data, Cooney and Uhlenberg (1989) showed that White women lawyers, physicians, and postsecondary teachers were substantially less likely than White women of the same age in the general population to be married and have children. Among White women between the ages of 35 and 39 with at least ten years of marriage, a substantially higher share of postsecondary teachers than of physicians or lawyers were childless (Cooney \& Uhlenberg, 1989).

Although the challenges associated with balancing work and family roles may not be unique to faculty, these data raise important questions not only about the extent to which marriage and motherhood may limit access to a faculty career in general but also about the specific types of academic positions that are available to married women and women with children. Of particular concern is the extent to which married women and women with children may be concentrated in lower-status faculty positions. Although the representation of women among college and university faculty has increased since the mid-1970s, the greatest growth has been among part-time and nontenure-track appointments (Chronister, Gansneder, Harper, \& Baldwin, 1997; Lomperis, 1990). While the number of nontenured but tenure-track full-time faculty increased between 1976 and 1993 at a faster rate for women than men (22\% increase for women versus $24 \%$ decline for men), the greatest growth has been among non-tenure track appointments. Between 1976 and 1993, the number of non-tenure track full-time faculty increased by $142 \%$ for women and 54\% for men (Chronister et al., 1997). In part because of these differential growth rates, analyses of the NSOPF:93 show that women represented a higher share of full-time, nontenure-track faculty than of full-time, tenure-track faculty in fall 1992 (52\% versus 43\%). 
Although anecdotal evidence (e.g., Flynn, Flynn, Grimm, \& Lockhart, 1986; Wilson, 1998) suggests that not all nontenure-track faculty are dissatisfied with their status, many nontenure-track faculty may be considered to be marginal "in the sense that they hope for full integration into academe" (Bowen \& Schuster, 1986, p. 65), and because they represent a lower rung on the hierarchy of academic labor markets (Youn, 1992). According to Youn (1992), the existence of hierarchies within the academic labor market contributes to various forms of segmentation including segmentation by job status (e.g., full-time or parttime). Movement from one job status segment to another (e.g., from part-time to full-time or from nontenure-track to tenure-track) is restricted, just as is movement from one academic discipline to another (e.g., from mathematics to English). Competition among faculty in different segments is limited, thereby permitting inequities among faculty across segments (Youn, 1992).

This study uses data from the NSOPF:93 to explore the extent to which the higher observed representation of women among nontenuretrack faculty (i.e., the lower status positions) is related to family responsibilities after taking into account other variables that are expected to be related to employment status. Sex differences in the relationship between family responsibilities and employment status are examined and implications of the findings are discussed.

\section{Theoretical Framework}

Although little is known about the relationship between family responsibilities and employment status among college and university faculty, researchers have explored the relationship between family responsibilities and such outcomes as research productivity and salaries. From her comprehensive review and synthesis of prior research, Creamer (1998) concluded that most research shows no relationship between marital status and publishing productivity for women. In fact, some evidence suggests that married faculty are more productive than other faculty after controlling for other differences (Bellas \& Toutkoushian, 1999). Some researchers (e.g., Astin \& Bayer, 1979; Astin \& Davis, 1985) have shown that married women, and others (e.g., Bellas, 1992; Hamovitch \& Morgenstern, 1977) have shown that married men are more productive than their single counterparts of the same sex. The extent to which the occupation of the spouse is related to scholarly productivity is equivocal. Using a national sample of faculty employed at colleges and universities in 1989, Astin and Milem (1997) found that, after controlling for differences in background and job-related characteristics, 
having an academic spouse was associated with higher levels of research productivity for women but lower levels of research productivity for men. In contrast, using a sample of faculty employed in the state of Illinois in 1993, Bellas (1997b) found that having an academic partner was unrelated to research productivity after taking into account differences in other variables.

With regard to the relationship between parental responsibilities and research productivity, Creamer (1998) also concluded from her review of prior research that the relationship is ambiguous. She found no significant relationship between having children and publishing productivity in five of the ten studies reviewed, a positive relationship in three of the ten, and a negative relationship in two of the ten. Using a subsample from the NSOPF:93, Bellas and Toutkoushian (1999) showed that fulltime faculty with dependents had higher levels of research productivity than full-time faculty without dependents after controlling for differences in sex, race, education, experience, academic field, institutional type, and allocation of time.

In terms of the relationship between family responsibilities and faculty salaries, Johnson and Stafford (1974), using data from the 1970 National Science Foundation Register, showed that labor force participation among women faculty was influenced by marital status, husband's earnings, and number of children and that time out of the labor force for child bearing and child rearing was negatively related to earnings. Whereas Barbezat (1988), after controlling for other variables, found marital status to be unrelated to the salaries of women and men faculty in both 1968 and 1977, others have shown that married men faculty received higher salaries than their single male counterparts in both 1984 (Bellas, 1992) and 1992 (Toutkoushian, 1998). Some research (Bellas, 1992; Astin \& Milem, 1997) suggests that the employment status of the spouse or partner also matters. Bellas (1992) found that men faculty with nonemployed wives averaged higher salaries than men faculty with employed wives even after controlling for education, experience, productivity, rank, institutional characteristics, and academic field. Astin and Milem (1997) found that, after controlling for differences in background and job-related characteristics, having an academic spouse was associated with higher salaries among women faculty but lower salaries among men faculty. Some research (Barbezat, 1988) indicates that men faculty, but not women faculty, with children receive higher salaries.

In one of the few examinations of the relationship between family responsibilities and employment status, Ferber and Hoffman (1997) found that neither the probability of being employed at a research or doctoral 
university nor the probability of holding the highest rank of full professor were related to such measures of household responsibilities as geographic distance from the current partner, number of years spent with partners, level of education of partners, number of years partners employed at the same institution, number of children, and number of years children spent in the household among women faculty employed at colleges and universities in the state of Illinois in 1993.

Prior research has drawn upon two perspectives to examine gender equity issues in academic employment: human capital and structural. According to human capital theory, an individual's status and rewards in the academic labor market are determined primarily by his or her productivity. Productivity is expected to be determined by the investments that individuals make in themselves, particularly the quantity and quality of their education and the amount of their on-the-job training, as well as their geographic mobility, their motivation and intensity of work, and their emotional and physical health (Becker, 1962, 1993).

Some economists have argued that family responsibilities influence investment in human capital, continuity of labor force participation, types of employment sought, and level of commitment to the job (Becker, 1985; Polachek, 1977). Even today family responsibilities continue to be borne primarily by women (Bond et al., 1997). For example, a 1997 national survey of workers in a variety of occupations showed that married employed women spent more time than married employed men caring for their children and engaging in household chores on both workdays and non-workdays (Bond et al., 1997).

With regard to the accumulation of human capital, an individual who is out of the labor force because of family responsibilities is not acquiring additional on-the-job experience and may even be losing some previously acquired job skills (Becker, 1993). Korenman and Neumark (1991) noted that most prior research has concluded that children reduce wages indirectly by reducing labor force participation and the "accumulation of human capital" (e.g., experience) rather than by directly reducing productivity. Arguing that prior estimates may be biased, however, Korenman and Neumark (1991) concluded that children may directly reduce women's wages and that, because of this reduction in wages, women reduce their participation in the labor market. Regardless of the direction of causality, women with children appear to average lower levels of experience.

Family responsibilities may also reduce geographic mobility. Research has shown that women are less mobile than men (Marwell, Rosenfeld, \& Spilerman, 1979; Rosenfeld \& Jones, 1987). For example, women have been found to be more likely than men to remain in the 
geographic area where they attended graduate school and to be concentrated in larger urban areas where, presumably, the probability of both partners finding satisfactory employment is higher (Marwell et al., 1979; Rosenfeld \& Jones, 1987). The advantages of geographic mobility are evidenced by research showing that faculty who are more mobile receive higher salaries (Astin \& Bayer, 1979; Smart \& McLaughlin, 1978; Kasten, 1984), are more likely to hold tenure track positions (Rosenfeld \& Jones, 1987), and tend to hold higher academic rank (Marwell et al., 1979) than other faculty.

Family responsibilities may also be related to the level of motivation and intensity of work. Human capital theorists (e.g., Becker, 1985) predict that, compared with men and single women, married women pursue less demanding jobs, such as part-time and nontenure-track positions, because household responsibilities require more effort than leisure and other nonmarket activities and, consequently, they have less energy available for market work. In other words, differences in household responsibilities are expected to be associated with differences in motivation and intensity of work and are expected to lead to occupational segregation by sex (Becker, 1985).

Marriage and parenting responsibilities may also influence emotional and physical health. As Tack and Patitu (1992) observed from their comprehensive review of the predictors of job satisfaction among women and minority faculty, "life-style stressors" (e.g., child care, parent care, physical and mental health) likely have a stronger impact on women than men because of societal expectations about the priority women should place on their families. Some (Austin \& Pilat, 1990) have speculated that women may also feel greater stress and pressure than men in their attempts to balance work and family responsibilities because of the physical demands of pregnancy, childbirth, and early parenthood.

Household responsibilities and children's problems have been shown to be more important sources of stress for women faculty than for men faculty (Dey, 1994). Among full-time tenure-track faculty at one university, $28 \%$ more women than men reported experiencing at least one of the following conflicts between work and child care: avoiding overnight conferences because of child care demands, bringing a child to the university, delaying promotion or tenure because of child care responsibilities, or being unavailable to attend a function at the child's school because of work demands (Riemenschnieder \& Harper, 1990). About two-thirds of women faculty, but only one-third of men faculty, reported feeling overwhelmed trying to meet both child care and employment demands (Riemenschnieder \& Harper, 1990). Findings from another single institution study suggest that women faculty are as involved with their 
work as men, but that women are more likely than men to forego leisure activities in order to satisfy work-related demands (Sorcinelli \& Near, 1989).

Despite the popularity of human capital theory for explaining differences in labor market experiences, some economists and sociologists have noted the limitations of this theory (DeYoung, 1989; Dreijmanis, 1991). Such critics argue that "focusing on the supply of human skills to explain economic inequality and lack of productivity is a theoretical mistake" (DeYoung, 1989, p. 155). Among the limitations is the inability of human capital theory to adequately explain the lower returns to educational investments among women and minorities (DeYoung, 1989). Based on her examination of the relationship between time out of the labor force and occupational choice, England (1982) concluded that "human capital theory has not generated an explanation of occupational sex segregation that fits the evidence" (p. 358). Contrary to the predictions of human capital theory, England's analyses of data from the National Longitudinal Survey showed that women with more continuous employment histories or plans were no less likely than other women to work in predominantly female occupations, the presumably lower-status occupations. In a test of Becker's (1985) assertion that women seek less demanding jobs and devote less effort to their jobs than men, Bielby and Bielby (1988) found that, after controlling for household responsibilities, earnings, and job responsibilities, women actually allocate more effort to their work than men.

Social scientists interested in the issues of social inequality and poverty have responded to the inadequacies of human capital theory by developing structural or institutional approaches to understanding labor markets (Youn, 1988). This perspective of labor market experiences generally emphasizes the effects of the attributes of the organizations with which individuals are connected, particularly the influence of the characteristics of the colleges and universities in which they were trained and in which they work, including these institutions' financial resources, tenure system, academic governance, and collective bargaining agreements.

Structural models posit that sex differences in the labor market experiences of faculty are attributable to the segregation of women in the types of institutions, academic fields, and work roles that have lower prestige and value (Smart, 1991). For example, Sorenson (1989) found that $20 \%$ of the national male-female wage difference in 1983 for all occupations, not just for faculty or higher education positions, was attributable to occupational segregation by sex after controlling for personal characteristics (e.g., tenure on the job, educational attainment, and fullor part-time status), characteristics of the occupation (e.g., education 
and training required to perform the job and working conditions), and attributes of the firm (e.g., geographic region, union status, size of firm, and major industry category). In higher education, the average salaries of faculty in institutions and disciplines with higher proportions of women have also been found to be lower than the average salaries of faculty in institutions and disciplines with smaller proportions of women (Barbezat, 1988; Bellas, 1994, 1997a; Smart, 1991).

\section{Research Method}

Although researchers have examined the effects of marital and parental status on research productivity and salaries, little is known about the relationship between family responsibilities and the employment status of faculty. Given the recent growth in nontenure-track positions, such research is particularly timely. Because some (e.g., Smart, 1991) have concluded that substantial research supports the appropriateness of both human capital and structural approaches to academic labor markets, this study draws upon both perspectives to explore the following research questions:

1. Are family responsibilities related to the employment status of women and men junior faculty after controlling for differences in human capital and structural characteristics?

2. To what extent are junior faculty satisfied holding nontenure-track positions?

\section{Sample}

Data from the NSOPF:93 are used to address the research questions. Sponsored by the U.S. Department of Education's National Center for Education Statistics, the NSOPF:93 is designed to provide a national profile of faculty, particularly with regard to their professional backgrounds, responsibilities, workloads, salaries, benefits, and attitudes. In the first stage of the two-stage sample selection, 974 public and private nonproprietary higher education institutions were selected and 817 agreed to participate. In the second stage, approximately 42 faculty and instructional staff were selected from each participating institution. A total of 25,780 questionnaires were returned by the 31,354 faculty and instructional staff who were sampled. For additional details on the survey methodology, refer to Kirshstein, Matheson, and Jing (1997).

The sample used in this research is limited to junior faculty whose primary responsibility is teaching. Junior faculty are defined as individuals with faculty status who hold tenure-track or nontenure-track posi- 
tions. Tenured faculty and faculty who work at colleges and universities that do not have a tenure system are excluded from the sample.

The NSOPF:93 weight (WEIGHT) is appropriate for approximating the population of college and university faculty from the sample. To minimize the influence of large sample sizes and correct for the nonsimple random sample design on standard errors, each case is weighted by the NSOPF:93 weight divided by the average weight for the sample (average weight $=37.72$ ). The adjusted weighted sample includes 6,505 cases and represents 245,382 junior faculty nationwide.

\section{Variables}

The hypothesized predictors of employment status include measures of family responsibilities, human capital, and structural characteristics. In addition to sex, four racial/ethnic groups are considered: Black, Hispanic, Asian, and White. White is the reference group. Family responsibilities are measured by marital status and parental status. Marital status is measured by three dichotomous variables: married (married or living with someone); previously married (separated, divorced, or widowed); and never married (reference category). Parental status is measured by whether the individual has at least one child (yes or no).

Human capital is accumulated via educational attainment, on-the-job training, experience, and mobility (Becker, 1962). The level of investment in formal education is measured by a three-level categorical variable: whether an individual holds less than a doctoral degree; whether an individual holds a doctoral degree from a non-Research I university; and whether an individual holds a doctoral degree from a Research I university (reference category). On-the-job training is measured by whether the individual held a research assistantship and/or a teaching assistantship during graduate school. Experience is measured by the number of years since receiving the highest degree and the number of years in the current position (correlation $=0.405$ ). Whether the individual is in his or her first or only job since having earned the highest degree (yes or no) is the best available proxy for mobility.

Structural attributes describe the type of institution and academic discipline in which a faculty member works. A categorical variable reflecting institutional Carnegie classification measures institutional resources as well as occupational segregation by institutional type. The categories are Research I (reference category), other Doctoral, Comprehensive I, other four-year, other (e.g., specialized), and two-year. The existence of collective bargaining agreements is measured by whether the faculty at the institution are unionized (yes or no). A measure of the tenure system, another structural attribute, is not necessary because only junior (i.e., 
nontenured) faculty working at institutions with a tenure system are included in the analyses. With regard to academic field, 12 categories are included to reflect substantive similarities as well as similarities in the representation of women among junior faculty in the field. The categories are nursing and other health (76\% women), English and foreign languages (67\%), education (66\%), fine arts (49\%), psychology, sociology, and other social sciences (48\%), biology (38\%), mathematics and computer science (33\%), business (31\%), history, philosophy, law, economics, and political science (31\%), first-professional health (30\%), engineering and physical science (15\%), and other field (40\% women). The reference category is engineering and physical science.

\section{Analyses}

The dependent variable, employment status, has four categories: employed full-time on a tenure track; employed part-time on a tenure track; employed full-time, not on a tenure track; and employed part-time, not on a tenure track. Because of the categorical nature of the dependent variable, a multinomial logit model, a special case of the general log-linear model, is used to examine the relationship between family responsibilities and employment status after controlling for human capital and structural characteristics. Part-time, tenure-track faculty are excluded from the multinomial logit analyses for two reasons. First, because the number of cases with part-time, tenure-track employment status is small (adjusted weighted sample size $=131,2 \%$ of all junior faculty), including a separate category for part-time, tenure-track employment would result in problems with zero cells and unstable estimates of coefficients and standard errors (Menard, 1995).

Second, combining part-time, tenure-track with one of the other groups is inappropriate because the descriptive analyses show that parttime, tenure-track faculty are different from other faculty in several respects. Table 1 shows that part-time employment appears to be more common at public two-year institutions regardless of tenure status, with about $44 \%$ of part-time, tenure-track and part-time, nontenure-track faculty employed at public two-year institutions. Part-time, tenure-track faculty are relatively less common at Research I universities, with only $3 \%$ of part-time, tenure-track faculty but $12 \%$ of all junior faculty working at Research I universities. Part-time, tenure track faculty have generally received their highest degrees more recently and have worked fewer years in their current positions than other junior faculty. Though marital status appears to be unrelated to employment status, a higher share of part-time, tenure-track faculty than of all junior faculty have at least one child (78\% versus $62 \%)$. 
Therefore, only three employment categories are considered in the multinomial logit model: (1) employed full-time, on a tenure track; (2) employed full-time, not on a tenure track; and (3) employed part-time, not on a tenure track. Two contrasts are possible with three outcome categories. Full-time, nontenure-track employment and part-time, nontenure-track employment are simultaneously contrasted to full-time, tenure-track employment.

Multinomial logit models estimate the log-odds of one outcome oc-

TABLE 1

Selected Characteristics of Women and Men Junior Faculty by Employment Status: Fall 1992

\begin{tabular}{|c|c|c|c|c|c|}
\hline Characteristic & Total & $\begin{array}{c}\text { Full-time } \\
\text { Tenure } \\
\text { Track }\end{array}$ & $\begin{array}{c}\text { Part-time } \\
\text { Tenure } \\
\text { Track }\end{array}$ & $\begin{array}{l}\text { Full-time } \\
\text { Nontenure } \\
\text { Track }\end{array}$ & $\begin{array}{l}\text { Part-time } \\
\text { Nontenure } \\
\text { Track }\end{array}$ \\
\hline Weighted sample & 245,382 & 4,928 & 87,592 & 35,442 & 117,420 \\
\hline Adjusted weighted $n$ & 6,505 & 131 & 2,322 & 940 & 3,113 \\
\hline Distribution & $100.0 \%$ & $35.7 \%$ & $2.0 \%$ & $14.4 \%$ & $47.9 \%$ \\
\hline InSTITUTIONAL TyPE & $100 \%$ & $100 \%$ & $100 \%$ & $100 \%$ & $100 \%$ \\
\hline Research I & $12.0 \%$ & $11.6 \%$ & $3.1 \%$ & $17.1 \%$ & $11.1 \%$ \\
\hline Other doctoral & $14.7 \%$ & $19.4 \%$ & $13.2 \%$ & $19.0 \%$ & $10.0 \%$ \\
\hline Comprehensive I & $25.2 \%$ & $30.1 \%$ & $20.2 \%$ & $28.4 \%$ & $20.7 \%$ \\
\hline Other 4-year & $12.3 \%$ & $15.3 \%$ & $10.1 \%$ & $14.5 \%$ & $9.4 \%$ \\
\hline Public 2-year & $29.7 \%$ & $18.4 \%$ & $45.0 \%$ & $12.1 \%$ & $42.8 \%$ \\
\hline UNIONIZED INSTITUTION & $44.8 \%$ & $41.1 \%$ & $51.1 \%$ & $41.5 \%$ & $48.3 \%$ \\
\hline WOMEN & $46.0 \%$ & $43.0 \%$ & $46.6 \%$ & $52.3 \%$ & $46.4 \%$ \\
\hline \multicolumn{6}{|l|}{ MARRIED } \\
\hline Total & $72.9 \%$ & $72.3 \%$ & $75.6 \%$ & $71.0 \%$ & $73.8 \%$ \\
\hline Men & $78.1 \%$ & $80.0 \%$ & $77.1 \%$ & $74.2 \%$ & $77.8 \%$ \\
\hline Women & $66.6 \%$ & $62.0 \%$ & $73.8 \%$ & $67.9 \%$ & $69.1 \%$ \\
\hline \multicolumn{6}{|l|}{ PreVIOUSLy MARried } \\
\hline Total & $12.8 \%$ & $12.3 \%$ & $9.2 \%$ & $12.1 \%$ & $13.5 \%$ \\
\hline Men & $9.3 \%$ & $7.9 \%$ & $2.9 \%$ & $10.7 \%$ & $10.4 \%$ \\
\hline Women & $16.9 \%$ & $18.1 \%$ & $18.0 \%$ & $13.6 \%$ & $17.2 \%$ \\
\hline \multicolumn{6}{|l|}{ AT LEAST 1 CHILD } \\
\hline Total & $62.1 \%$ & $62.6 \%$ & $77.7 \%$ & $58.2 \%$ & $62.2 \%$ \\
\hline Men & $69.7 \%$ & $71.0 \%$ & $82.9 \%$ & $62.6 \%$ & $70.1 \%$ \\
\hline Women & $53.1 \%$ & $51.5 \%$ & $70.5 \%$ & $54.2 \%$ & $53.1 \%$ \\
\hline \multicolumn{6}{|c|}{ LeSS THAN Doctoral DeGreE } \\
\hline Total & $66.2 \%$ & $40.3 \%$ & $81.3 \%$ & $71.4 \%$ & $83.5 \%$ \\
\hline Men & $61.0 \%$ & $34.6 \%$ & $76.5 \%$ & $69.2 \%$ & $79.4 \%$ \\
\hline Women & $72.1 \%$ & $47.8 \%$ & $86.7 \%$ & $73.4 \%$ & $88.0 \%$ \\
\hline \multicolumn{6}{|c|}{ No. Years Since Highest Degree } \\
\hline Total & 12.1 & 13.0 & 8.7 & 11.8 & 14.9 \\
\hline Men & 13.0 & 13.8 & 8.9 & 13.6 & 16.1 \\
\hline Women & 11.1 & 12.1 & 8.3 & 10.1 & 13.4 \\
\hline \multicolumn{6}{|c|}{ No. YEARS IN CURRENT POSITION } \\
\hline Total & 5.5 & 7.7 & 4.2 & 6.0 & 6.2 \\
\hline Men & 6.0 & 8.8 & 4.4 & 6.3 & 7.1 \\
\hline Women & 4.9 & 6.3 & 4.0 & 5.7 & 5.2 \\
\hline
\end{tabular}

SouRCE: Analyses of 1993 National Study of Postsecondary Faculty (NSOPF:93). 
curring relative to the baseline category (i.e., full-time, tenure track employment). If the baseline category is $J$, the model for the $i^{\text {th }}$ category (e.g., full-time, nontenure-track employment) is:

$$
\log \left(\mathrm{P}_{\mathrm{i}} / \mathrm{P}_{\mathrm{j}}\right)=B_{\mathrm{i} 0}+B_{\mathrm{i} 1} \mathrm{X}_{1}+B_{\mathrm{i} 2} \mathrm{X}_{2}+\ldots+B_{\mathrm{ip}} \mathrm{X}_{\mathrm{p}}
$$

The logistic coefficients that result from this equation may be interpreted as the change in log odds associated with a one-unit change in the independent variable. The interpretation of the multinomial logit coefficients is facilitated by the use of odds-ratios, as described by the following equation:

$$
\mathrm{P}_{\mathrm{i}} / \mathrm{P}_{\mathrm{j}}=\mathrm{e}^{B_{\mathrm{i} 0}+B_{\mathrm{i} 1} \mathrm{X}_{1}+\ldots+B_{\mathrm{ip}} \mathrm{X}_{\mathrm{p}}}=\mathrm{e}^{B_{\mathrm{i} 0}} \mathrm{e}^{B_{\mathrm{i} 1} \mathrm{X}_{1} \ldots \mathrm{e}^{B_{\mathrm{ip}} \mathrm{X}_{\mathrm{p}}}}
$$

The odds-ratio represents the change in the odds of choosing a particular employment status relative to the reference employment status (fulltime tenure-track) that is associated with a one-unit change in a particular independent variable. An odds-ratio greater than one represents an increase in the likelihood of part-time or full-time, nontenure-track employment relative to full-time, tenure-track employment, whereas an odds-ratio less than one represents a decrease in the likelihood of parttime or full-time, nontenure-track employment.

The two continuous variables, number of years since receiving the highest degree and number of years in the current position, are entered into the model as covariates. The test of whether a coefficient is different from zero is based on the Wald statistic, which is calculated as the coefficient divided by its standard error, squared. Goodness-of-fit is reflected by the change in $-2 \log$ likelihood. A pseudo- $R^{2}$ is reported to provide an indication of the strength of the relationship between the outcome variable and the independent variables.

\section{Limitations}

One of the limitations of this study is that the analyses exclude individuals who have chosen not to hold a faculty position. In other words, only individuals who have chosen to try to balance work and family (as evidenced by their presence in the sample) are included in the analyses. Descriptive analyses suggest that comparable proportions of women and men junior faculty are in their prime childbearing years (under age 40) (about 36\%). This suggests that women are no more likely than men to "opt out" of faculty careers because they want marriage and parenting to be a part of their lives. Nonetheless, because of the lack of information about qualified individuals who decide not to pursue faculty careers, the findings from this research may underestimate the relationship between family responsibilities and employment status. 
A second limitation of this study pertains to the adequacy of the available variables in the database. Although the NSOPF:93 has many strengths, the database includes few direct measures of family responsibilities. Examples of important, but unavailable, variables include the ages of dependent children, timing of childbearing, childcare arrangements, employment status and occupation (e.g., academic or nonacademic) of the spouse, income of the spouse, amount of time spent out of the labor force because of family responsibilities, time devoted to household chores, and time devoted to child care. The NSOPF:93 also lacks measures of parent care-giving, a potentially important influence on employment status given that a 1997 survey found that $25 \%$ of the wage and salaried labor force nationwide had elder care responsibilities during the prior year, that employees with elder care responsibilities provided an average of 11 hours per week in assistance, and that $37 \%$ of employees with elder care responsibilities took time off from work to provide that assistance (Bond, Galinsky, \& Swanberg, 1997). In addition, although holding the first or only job since earning the highest degree may be an inadequate proxy for mobility, the NSOPF:93 lacks appropriate alternative measures.

A third limitation pertains to the difficulty of determining the direction of causality between family responsibilities and employment status using this cross-sectional database. Therefore, this study focuses on exploring the relationship between family responsibilities and employment status among junior faculty, rather than on drawing conclusions about causality. To more fully explore the intercorrelations among the variables in the model, the analytic strategy involves entering conceptually related variables together. Sex and race are entered into the model first. Then family responsibilities are added to determine whether family responsibilities are related to employment status apart from the influence of human capital and structural characteristics. Measures of human capital are then entered into the model, followed by measures of structural characteristics.

\section{Findings}

Observed Relationships Between Family Responsibilities and Employment Status

The descriptive analyses suggest that women junior faculty hold a relatively higher proportion of full-time, nontenure-track positions and a relatively smaller proportion of full-time, tenure-track positions. Table 1 shows that women represent $52 \%$ of full-time, nontenure-track faculty, $47 \%$ of part-time, tenure-track faculty, $46 \%$ of part-time, nontenuretrack faculty, and $43 \%$ of full-time, tenure-track faculty. 
Regardless of employment status, a smaller proportion of women than men are married (67\% versus $78 \%$ overall), but a higher proportion of women than men were previously married (17\% versus $9 \%$ overall). Only 53\% of women junior faculty have at least one child, compared with $70 \%$ of men junior faculty. A higher percentage of part-time, tenure-track faculty than of junior faculty overall are observed to have at least one child among both women (71\% versus 53\%) and men $(83 \%$ versus $70 \%$ ) junior faculty.

Relationship Between Family Responsibilities and Employment Status Controlling for Other Variables

Table 2 shows the odds-ratios for full-time, nontenure-track employment and part-time, nontenure-track employment relative to full-time, tenure-track employment among junior faculty. Columns 1 and 2 represent the "baseline" model that includes only measures of sex and race. Columns 3 and 4 show the relationship between family responsibilities and employment status controlling for differences in sex and race. Columns 5 and 6 show the odds-ratios when human capital characteristics are added to the model, and columns 7 and 8 show the odds-ratios when structural characteristics are also taken into account. The likelihood ratio test indicating the probability that all of the variables in the model are jointly equal to zero is rejected at the $0.1 \%$ level for all specifications.

The multinomial logistic regression analyses reveal that, controlling only for race, women are more likely to hold both full-time and part-time, nontenure-track positions than full-time, tenure-track positions (columns $1 \& 2$ ). Adding controls for family responsibilities does not change the relationship between sex and employment status (columns $3 \& 4$ ). Adding measures of human capital to the model eliminates the statistically significant relationship between sex and the likelihood of holding a part-time, nontenure-track position rather than a full-time, tenure-track position (column 6). Even after controlling for differences in race, family responsibilities, human capital, and structural characteristics, however, the odds of holding a full-time, nontenure-track position rather than a full-time, tenure-track position are higher for women than for men. These findings suggest that differences in race, family responsibilities, human capital, and structural characteristics do not fully account for the observed higher representation of women in full-time, nontenure-track positions.

Married faculty and previously married faculty are more likely than never married faculty to hold part-time, nontenure-track positions than full-time, tenure-track positions after controlling only for sex and race (column 4). Controlling also for human capital investment, however, eliminates these relationships (column 6). Contrary to expectations 


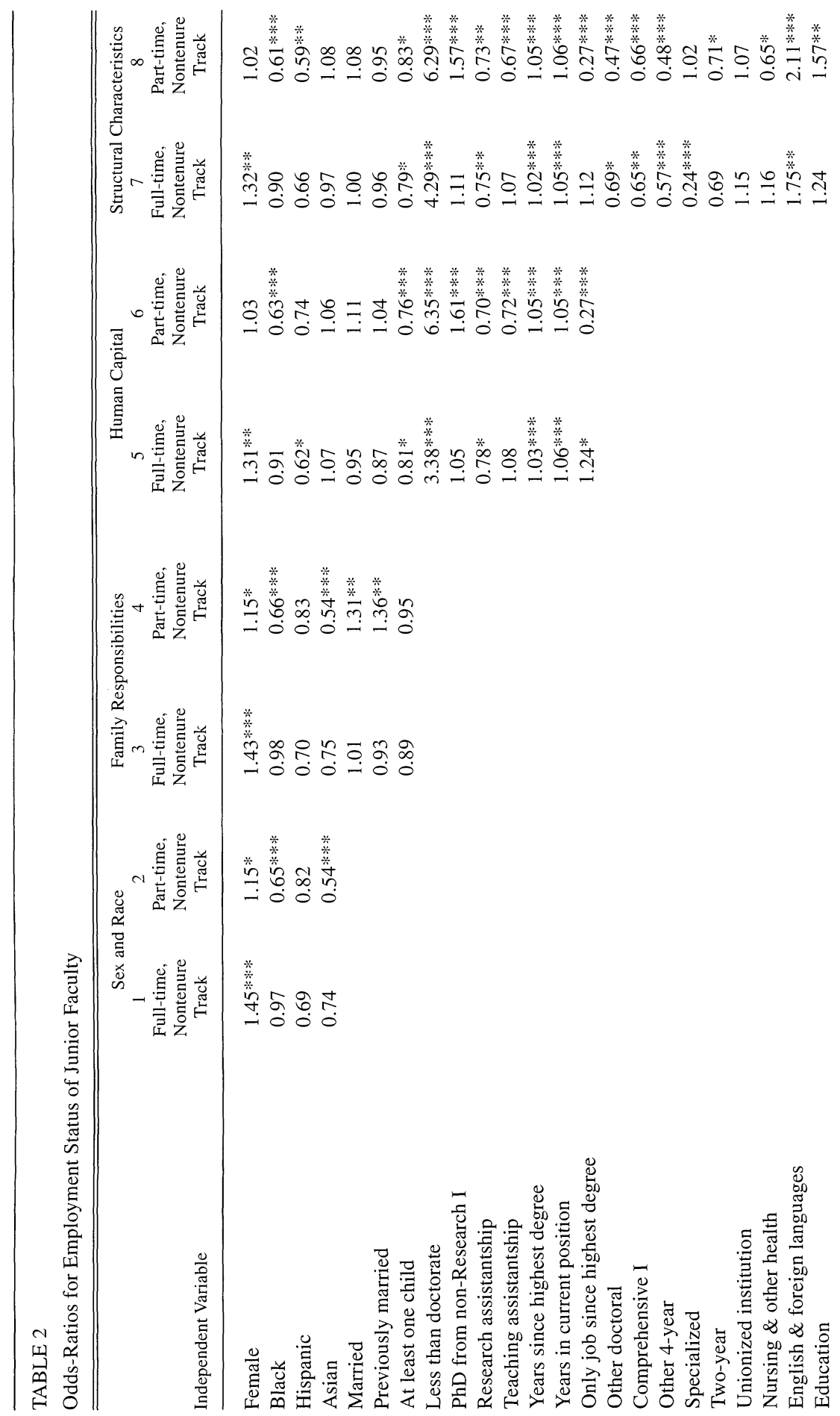




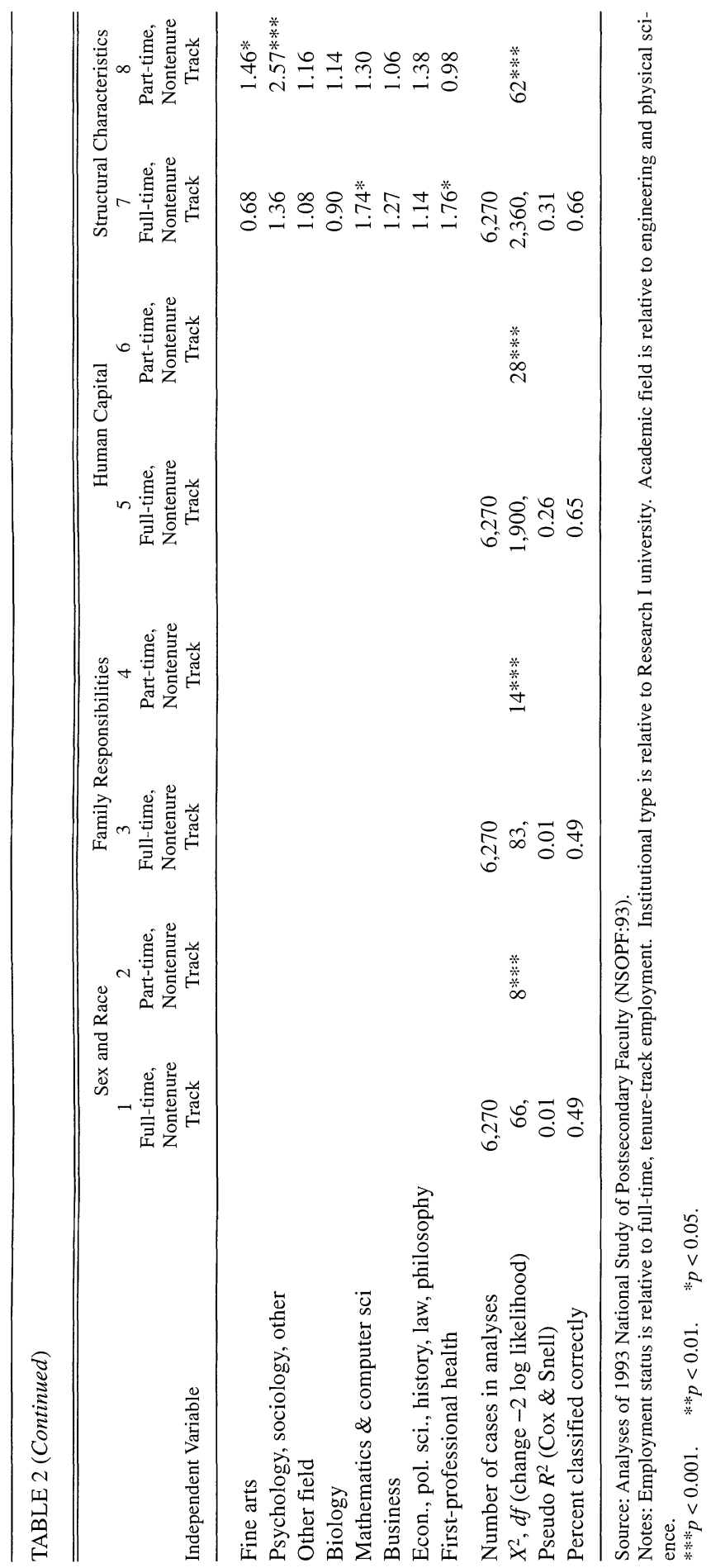


based on human capital theory, junior faculty with at least one child are marginally $(p<0.05)$ less likely to hold both full-time and part-time, nontenure-track positions than full-time, tenure-track positions even after controlling for differences in other variables.

The analyses also reveal that educational attainment is an important predictor of employment status. The odds of holding either a full-time or part-time, nontenure-track position rather than a full-time, tenure-track position are substantially higher for faculty who have not earned a doctorate even after taking other differences into account. Holding a research assistantship during graduate school reduces the odds of holding either a full-time or part-time, nontenure-track position, net of other variables, while holding a teaching assistantship reduces the odds of holding a part-time, nontenure-track position. Junior faculty at non-Research I four-year colleges and universities appear to be less likely than junior faculty at Research I universities to hold full-time or part-time, nontenure-track positions. The odds of holding a part-time, nontenuretrack position appear to be higher for faculty working in fields with among the highest proportions of women, English and foreign languages, education, fine arts, and psychology, sociology, and other social sciences. In contrast, faculty in the category with the highest proportion of women, nursing and non-first professional health, appear to be less likely to hold part-time, nontenure-track positions. These findings suggest that the concentration of women in particular academic fields may be related to the segregation of women by employment status.

To more fully explore sex differences in the relationship between family responsibilities and employment status, the analyses are repeated for women and men separately. The results, summarized in Table 3, show that, consistent with human capital theory, the odds of holding a parttime, nontenure-track position appear to be higher for married women than for other women even after controlling for race, human capital investment, and structural characteristics. Marital status appears to be unrelated to employment status among men junior faculty. Whereas having at least one child is unrelated to employment status for women junior faculty after controlling for other variables, men who have at least one child appear to be less likely than their childless male counterparts to hold a full-time, nontenure-track position.

\section{Satisfaction with Nontenure-Track Employment Among Junior Faculty}

Anecdotal evidence suggests that some fraction of nontenure-track faculty are content with their employment status because they prefer to spend their time on other well-paying jobs, hobbies, or raising children 
TABLE 3

Odds-Ratios for Employment Status of Women and Men Junior Faculty: Fall 1992

\begin{tabular}{|c|c|c|c|c|}
\hline \multirow[b]{2}{*}{ Independent Variable } & \multicolumn{2}{|c|}{ Full-time, Nontenure Track } & \multicolumn{2}{|c|}{ Part-time, Nontenure Track } \\
\hline & Women & Men & Women & Men \\
\hline Black & 0.81 & 1.01 & $0.45^{* * * * *}$ & 0.78 \\
\hline Hispanic & 0.48 & 0.79 & 0.84 & $0.45^{* * * *}$ \\
\hline Asian & 1.17 & 0.95 & 1.19 & 1.00 \\
\hline Married & 1.09 & 0.95 & $1.41 *$ & 0.78 \\
\hline Previously married & 0.85 & 1.11 & 1.10 & 0.84 \\
\hline At least one child & 0.99 & $0.62 * *$ & 0.90 & 0.82 \\
\hline Less than doctorate & $4.12^{* * * *}$ & $4.44 * * * * *$ & $8.34 * * *$ & 5.29 **** \\
\hline $\mathrm{PhD}$ from non-Research I & 1.42 & 0.91 & $2.09 * * * *$ & 1.29 \\
\hline Research assistantship & $0.64 * *$ & 0.84 & $0.65^{* *}$ & 0.82 \\
\hline Teaching assistantship & 1.10 & 1.05 & $0.63 * * *$ & $0.68 * * *$ \\
\hline Number of years since highest degree & 1.00 & $1.04 * * * *$ & $1.04 * * *$ & $1.06 * * * *$ \\
\hline Number of years in current position & $1.08 * * * *$ & $1.04 * *$ & $1.05^{*} * *$ & $1.06^{* * * * *}$ \\
\hline Only job since highest degree & 0.84 & $1.42 *$ & $0.31 * * *$ & $0.21^{* * * *}$ \\
\hline Unionized institution & 0.97 & $1.31 *$ & 0.88 & $1.29 * *$ \\
\hline Other doctoral & $0.55^{* * *}$ & 0.89 & 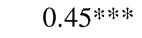 & $0.53^{* * * * *}$ \\
\hline Comprehensive I & $0.43 * * *$ & 0.98 & $0.61^{* * *}$ & $0.73^{*}$ \\
\hline Other 4-year & $0.31 * * *$ & 1.08 & $0.40 * * * *$ & $0.58 * *$ \\
\hline Two-year & $0.14^{* * * *}$ & $0.45^{* * *}$ & 0.85 & 1.33 \\
\hline Specialized institution & $0.50^{*}$ & 0.92 & 0.94 & $0.61 *$ \\
\hline Nursing \& other health & 1.30 & 0.93 & 0.68 & 1.03 \\
\hline English \& foreign languages & 2.04 & $1.79 *$ & $3.07 * *$ & $1.62 *$ \\
\hline Education & 1.26 & 1.52 & $2.29 *$ & 1.21 \\
\hline Fine arts & 1.02 & $0.48 *$ & $2.39 *$ & 1.15 \\
\hline Psychology, sociology, other & 1.57 & 1.34 & 3.60 **** & $2.29 * * * *$ \\
\hline Other field & 1.03 & 1.14 & 1.18 & 1.30 \\
\hline Biology & 1.13 & 0.80 & 1.69 & 1.00 \\
\hline Mathematics \& computer science & 1.91 & $1.76^{*}$ & 1.24 & 1.49 \\
\hline Business & 1.52 & 0.83 & 1.29 & 1.21 \\
\hline Econ., pol. sci., history, law, philosophy & 1.55 & 0.93 & 1.84 & 1.28 \\
\hline First-professional health & 1.56 & $2.00 *$ & 0.89 & 1.12 \\
\hline Number of cases in the analyses & 2,902 & 3,368 & & \\
\hline$R^{2}, d f$ (change -2 log likelihood) & $1,081,60 * * *$ & $1,407,60^{* * * *}$ & & \\
\hline Pseudo $R^{2}$ (Cox \& Snell) & 0.311 & 0.341 & & \\
\hline Percent classified correctly & $66 \%$ & $68 \%$ & & \\
\hline
\end{tabular}

SouRCE: Analyses of 1993 National Study of Postsecondary Faculty (NSOPF:93).

NOTES: Employment status is relative to full-time, tenure-track employment. Institutional type is relative to Research I university. Academic field is relative to engineering and physical science.

$* * * p<0.001 . \quad * * p<0.01$. * $p<0.05$.

(Flynn, Flynn, Grimm \& Lockhart, 1986; Wilson, 1998). Exploring the extent to which junior faculty are satisfied holding part-time and nontenure-track positions is limited by the variables available in the NSOPF:93 database. For example, part-time faculty, but not full-time, nontenure-track faculty, were asked their reasons for their current 
employment status. Descriptive analyses of the available data reveal that women and men are equally likely to report holding part-time, nontenure-track positions because they prefer to work part-time (about $56 \%$ ). Table 4 shows that women are more likely than men to report holding a part-time, nontenure-track position because a full-time position is unavailable (49\% versus $38 \%$ ) but less likely to report holding a part-time, nontenure-track position because they are supplementing their incomes (48\% versus $61 \%$ ). These data suggest that, despite a generally stated preference for working part-time, women may actually be less likely than men to hold part-time, nontenure-track positions because they have voluntarily chosen such status.

Another approach to understanding the extent to which junior faculty are satisfied holding nontenure-track positions is to examine the relative importance of various characteristics in a decision to leave the current job. The descriptive data presented in Table 5 suggest that, among both women and men, the prospect of a tenured position is somewhat less important for faculty holding nontenure-track positions than for faculty holding full-time, tenure-track positions (about 47\% versus 64\%). Opportunity for advancement and job security are very important for most faculty, although both appear to be somewhat less important for parttime, nontenure-track faculty than for full-time, tenure-track faculty. Despite these differences, the data suggest that a substantial portion of women and men nontenure-track faculty are interested in a tenured position, opportunity for advancement, and job security. The importance of some characteristics that are likely associated with family responsibilities, such as geographic location and schools for children, does not appear to vary by employment status. Among both women and men, the

TABLE 4

Reasons Part-time, Nontenure-Track Faculty Are Working Part-time: Fall 1992

\begin{tabular}{|c|c|c|c|c|}
\hline Characteristic & Total & Women & Men & $\begin{array}{l}\text { Statistical } \\
\text { Difference }\end{array}$ \\
\hline Total & $100 \%$ & $100 \%$ & $100 \%$ & \\
\hline Preferred part-time & $56 \%$ & $55 \%$ & $57 \%$ & n.s. \\
\hline Full-time unavailable & $43 \%$ & $49 \%$ & $38 \%$ & **** \\
\hline Supplementing income & $55 \%$ & $48 \%$ & $61 \%$ & $* * * *$ \\
\hline To be in academic environment & $71 \%$ & $71 \%$ & $71 \%$ & n.s. \\
\hline Finishing graduate degree & $9 \%$ & $11 \%$ & $7 \%$ & $* * *$ \\
\hline Other reason & $20 \%$ & $20 \%$ & $20 \%$ & n.s. \\
\hline
\end{tabular}

SOURCE: Analyses of 1993 National Study of Postsecondary Faculty (NSOPF:93). NOTE: n.s. indicates not statistically significant.

$* * * p<0.001 . \quad * * p<0.01 . \quad * p<0.05$. 
availability of a job for the spouse appears to be somewhat less important for part-time, nontenure-track faculty than for full-time faculty. Regardless of employment status, however, spousal employment appears to be a more important concern for women than for men. Nonetheless, both women and men junior faculty appear to be satisfied with their choice of profession regardless of employment status. Table 6 shows that, on average, both women and men junior faculty generally agree that they would choose an academic career again.

\section{Conclusions and Implications}

Although Bowen and Schuster (1986) predicted that differences in the status of, and rewards received by, women and men faculty would diminish as the number of women entering academic careers continued to increase, the findings from this study show that sex differences continue to exist in employment status. Even after controlling for differences in race, family responsibilities, human capital, and structural characteristics, women are more likely than men to hold full-time, nontenure positions, positions of lower status in the academic labor market hierarchy.

TABLE 5

Percent of Junior Faculty Reporting Various Characteristics to be Very Important in the Decision to Leave Current Job: Fall 1992

\begin{tabular}{llllll}
\hline \hline Characteristic & Sex & Total & $\begin{array}{c}\text { Full-time, } \\
\text { Tenure Track }\end{array}$ & $\begin{array}{c}\text { Full-time, } \\
\text { Nontenure Track }\end{array}$ & $\begin{array}{c}\text { Part-time, } \\
\text { Nontenure Track }\end{array}$ \\
\hline Tenured position & Total & $51 \%$ & $64 \%$ & $47 \%$ & $42 \%$ \\
& Women & $52 \%$ & $65 \%$ & $48 \%$ & $44 \%$ \\
Opportunity advancement & Men & $50 \%$ & $64 \%$ & $46 \%$ & $40 \%$ \\
& Total & $61 \%$ & $66 \%$ & $62 \%$ & $57 \%$ \\
Job security & Men & $63 \%$ & $69 \%$ & $65 \%$ & $59 \%$ \\
& Total & $59 \%$ & $64 \%$ & $59 \%$ & $55 \%$ \\
Geographic location & Women & $72 \%$ & $76 \%$ & $77 \%$ & $63 \%$ \\
& Men & $64 \%$ & $72 \%$ & $66 \%$ & $69 \%$ \\
Schools for children & Total & $59 \%$ & $61 \%$ & $58 \%$ & $57 \%$ \\
& Women & $61 \%$ & $63 \%$ & $60 \%$ & $58 \%$ \\
& Men & $58 \%$ & $60 \%$ & $56 \%$ & $55 \%$ \\
Job for spouse & Total & $54 \%$ & $58 \%$ & $53 \%$ & $52 \%$ \\
& Women & $53 \%$ & $53 \%$ & $54 \%$ & $52 \%$ \\
& Men & $55 \%$ & $62 \%$ & $52 \%$ & $51 \%$ \\
& Total & $44 \%$ & $51 \%$ & $48 \%$ & $37 \%$ \\
& Women & $49 \%$ & $56 \%$ & $57 \%$ & $42 \%$ \\
& Men & $39 \%$ & $48 \%$ & $39 \%$ & $33 \%$ \\
\hline
\end{tabular}

SOURCE: Analyses of 1993 National Study of Postsecondary Faculty (NSOPF:93). 
TABLE 6

Level of Agreement that a Junior Faculty Member Would Choose an Academic Career Again: Fall 1992

\begin{tabular}{lcccc}
\hline \hline Sex & Total & $\begin{array}{c}\text { Full-time, } \\
\text { Tenure Track }\end{array}$ & $\begin{array}{c}\text { Full-time, } \\
\text { Nontenure Track }\end{array}$ & $\begin{array}{c}\text { Part-time, } \\
\text { Nontenure Track }\end{array}$ \\
\hline Women & 3.43 & 3.45 & 3.40 & 3.40 \\
Men & 3.45 & 3.46 & 3.42 & 3.45 \\
\hline
\end{tabular}

SOURCE: Analyses of 1993 National Study of Postsecondary Faculty (NSOPF:93).

NOTE: Scale is from 1 to 4 , with 1 indicating strongly disagree and 4 indicating strongly agree.

Though both human capital and structural approaches were shown to be useful for understanding the distribution of faculty by employment status, the results of this research suggest that human capital and structural approaches to the academic labor market do not fully account for the concentration of women in full-time, nontenure-track positions. One possible explanation for this finding is that the model omitted, or inadequately measured, important aspects of human capital and structural characteristics, as described in the limitations section. A second possible explanation is that women prefer to hold full-time, nontenure-track positions for reasons that are not adequately captured by the available proxies for family responsibilities. The finding that about $55 \%$ of women with part-time, nontenure-track appointments prefer to work part-time may be consistent with this explanation. Alternatively, women may be more likely to hold these lower status positions because they are perceived by colleges and universities to be less productive and/or incapable of succeeding in full-time, tenure-track positions. The descriptive data showing that a higher share of women than men are working parttime because a full-time position is unavailable may support the appropriateness of this explanation.

The findings from this study also suggest that the employment of women in nontenure-track positions is attributable in part to their marital and parental status. Although a smaller share of women than men junior faculty are married (67\% versus $78 \%$ ), being married increases the odds of holding a part-time, nontenure-track position for women but not for men. While a smaller share of women than men junior faculty have at least one child (53\% versus $70 \%$ ), having at least one child reduces the odds of holding a full-time, nontenure-track position for men but is unrelated to employment status for women. As Toutkoushian (1998) noted, these sex differences in employment status for women and men faculty may be attributable to either differences in the supply of women and 
men faculty who are married or parents or to differences in the demand for faculty who are married or parents. Regardless, while some research (e.g., Bellas, 1992; Toutkoushian, 1998) has shown that married men faculty benefit from having wives in terms of their productivity and salaries, this study suggests that married men faculty and men faculty with children are also benefiting from their marital and parental status in terms of their employment status.

Because the NSOPF:93 lacks variables describing the nature of the spouse's employment, future research should examine the extent to which married women are more likely to hold part-time, nontenure-track positions because they are married to other academics. Using a national survey of college and university faculty in 1989, Astin and Milem (1997) showed that a higher share of married women faculty than married men faculty are married to other academics (40\% versus 35\%). Whereas some research suggests that women with academic spouses may be benefitting in terms of their productivity, rank, and salaries possibly because of greater access to collegial networks (Astin \& Milem, 1997), this study suggests that married women-a substantial proportion of whom are likely to have academic spouses - may be disadvantaged with regard to their employment status because of a lack of mobility.

On the surface, the descriptive analyses suggest that a substantial portion of women and men junior faculty are relatively satisfied holding lower status (i.e., nontenure-track) positions. Regardless of employment status, both women and men generally agreed that they would choose an academic career again. Nonetheless, future research should also further explore the satisfaction of women and men nontenure-track faculty, particularly given the conclusion of Tack and Patitu (1992) that many married women faculty may be "diluting their professional ambitions and assuming part-time faculty positions" because the demands of work and family are too overwhelming (p. 53).

To some extent, the participation of women in the labor force may always be limited by family responsibilities (Hough, 1987). Even though the share of men who are assuming care-giving responsibilities is growing (Bond et al., 1997), the effects of marital and parental responsibilities on faculty careers are likely to continue to be greater for women than men (Gappa \& Leslie, 1993). Dual career relationships typically require one or both partners to make sacrifices regarding career opportunities, particularly in terms of where to live (Gappa \& Leslie, 1993). Marriage is likely to impose a greater hardship on the career development and advancement of women than men because a higher percentage of employed women than of employed men are in dual career marriages (89\% versus 69\%) (Bond et al., 1997). Moreover, even in the 1990s, 
many families may focus on maximizing the husband's rather than the wife's employment status (Marwell et al., 1979). McElrath (1992) found that, among criminology faculty, women were three times as likely to interrupt their careers because of reasons related to their husband's employment than for maternity. After controlling for education, experience, publications, and parental status, a career disruption and the number of job changes were associated with a lower probability of tenure for women and, among tenured women, a longer time to tenure. In contrast, career disruptions and job changes were unrelated to either the probability of being tenured or the number of years to tenure among men (McElrath, 1992). The findings from this study further suggest that the effects of family responsibilities are less advantageous for women than for men.

Some critics of human capital theory have argued that "many workers who could contribute to the economic advance of the nation have been confined to low-status jobs where they are not allowed to be productive" (DeYoung, 1989, p. 161). Because of the challenges Youn (1992) identifies with moving across segments of the academic labor market, faculty who hold nontenure-track appointments but who aspire to tenure-track or tenured appointments are unlikely to achieve their goal. A number of researchers (e.g., Bowen \& Schuster, 1986; Chronister, Baldwin \& Bailey, 1996; Franklin, Laurence, \& Denham, 1988; Gappa \& Leslie, 1993; Kasper, Bronner, Gray, Kreiser, \& Rosenthal, 1986; Lomperis, 1990; Rajagopal \& Farr, 1992;) have concluded that part-time and nontenuretrack faculty generally receive less encouragement and support for research activities, as evidenced by their less desirable teaching assignments and heavier teaching loads, lack of collegial support, and lack of access to resources for research including release time, funding, and facilities.

From an institutional perspective, the use of nontenure-track faculty may appear to have some financial and programmatic advantages. Nontenure-track appointments may provide colleges and universities with greater flexibility to respond to enrollment changes and shifts in enrollment across academic disciplines and may enable them to offer specialized courses without the commitment of resources that a tenure-track appointment entails. Nonetheless, Kasper et al. (1986), Franklin et al. (1988), and others have argued that the increasing use of part-time and nontenure-track faculty undermines academic standards and diminishes the quality of undergraduate education. Gappa and Leslie (1993) concluded, based on their examination of the use of part-time faculty at 18 colleges and universities, that using part-time faculty does not necessarily improve efficiency or cost effectiveness. As an example, the use of part-time and nontenure-track faculty typically requires that tenured and 
tenure track full-time faculty assume the burden of student advising, committee work, and other activities in which nontenure-track faculty do not fully participate.

Although some (e.g., Franklin et al., 1988) have recommended that some nontenure-track positions be converted to tenure-track assistant professor appointments, nontenure-track faculty are likely to continue to comprise a substantial proportion of our nation's faculty (Gappa \& Leslie, 1993). The findings from this research suggest that individual colleges and universities should reexamine their policies and procedures regarding recruitment and tenure. With regard to recruitment, institutions should ensure that the tendency of women to hold full-time, nontenure-track positions rather than full-time, tenure-track positions is attributable to a genuine preference for such positions. Colleges and universities should also examine their policies and procedures regarding tenure to ensure that women are not pressured to choose between a tenure-track position and motherhood. This study showed that only $2 \%$ of junior faculty nationwide hold part-time, tenure-track positions. Of 191 colleges and universities in one survey, only $11 \%$ had a policy offering tenure to part-time faculty (Raabe, 1997). By creating flexibility in the tenure process (e.g., by allowing part-time faculty to pursue tenure), and by ensuring that all administrators and faculty understand the need for such policies (Finkel et al., 1994), colleges and universities will help to establish a more "family friendly" environment.

As others (e.g., Marshall \& Jones, 1990; Sorcinelli \& Near, 1989) have suggested, all faculty would benefit from institutional efforts that support faculty in managing work and family roles. The Families and Work Institute concluded from its 1997 survey of employees in a variety of occupations nationwide that a supportive workplace environment is critical to the effectiveness, satisfaction, commitment, and retention of workers regardless of industry (Bond et al., 1997). A study of faculty at one university suggests that job and life satisfaction are more highly correlated among college and university faculty than among the general population (Sorcinelli \& Near, 1989). Both married men and women with children are concerned about dual careers, commuter marriages, and childrearing (Sorcinelli \& Near, 1989). Therefore, all faculty would likely benefit from such initiatives as workshops on time and stress management and sex role socialization, supportive counseling (especially during family and career changes), higher quality and more available childcare, and employment assistance for spouses and partners, as well as more flexible leaves and sabbaticals. Nonetheless, a 1991 survey of 191 colleges and universities showed that, while most institutions had a policy regarding unpaid or paid leave for mothers at childbirth, less than 
one-half had policies covering job assistance for the spouse, accommodative scheduling, unpaid leave for fathers at childbirth, or on-campus childcare centers (Raabe, 1997). Moreover, even when such policies as accommodative scheduling and job sharing are in place, they are reported to be only rarely used (Raabe, 1997). By adopting and encouraging the use of policies, practices, and initiatives that recognize that many faculty are also spouses and parents, colleges and universities will create an environment that fosters the success of both women and men faculty.

\section{References}

Astin, H. S., \& Bayer, A. E. (1979). Pervasive sex differences in the academic reward system. In D. R. Lewis \& W. E. Becker (Eds.), Academic Rewards in Higher Education (Chap. 10). Cambridge, MA: Balinger.

Astin, H. S., \& Davis, D. E. (1985). Research productivity across the life and career cycles: Facilitators and barriers for women. In M. F. Fox (Ed.), Scholarly writing and publishing: Issues, problems, and solutions. Boulder, CO: Westview Press.

Astin, H. S., \& Milem, J. F. (1997). The status of academic couples in U.S. institutions. In M. A. Ferber \& J. W. Loeb (Eds.), Academic couples: Problems and Promises (pp. 128-155). Urbana: University of Illinois Press.

Austin, A. E., \& Pilat, M. (1990). Tension, stress, and the tapestry of faculty lives. Academe, 77, 38-42.

Barbezat, D. (1988). Gender differences in the academic reward system. In D. W. Breneman \& T. I. Youn (Eds.), Academic labor markets and careers (pp. 138-164). New York: The Falmer Press.

Becker, G. S. (1962). Investment in human capital: A theoretical analysis. Journal of Political Economy, 70 Supplement (5), 9-49.

Becker, G. S. (1985). Human capital, effort, and the sexual division of labor. Journal of Labor Economics, 3(1), S33-S58.

Becker, G. S. (1993). Human capital. Chicago: University of Chicago Press.

Bellas, M. L. (1992). The effects of marital status and wives' employment on the salaries of faculty men: The (house) wife bonus. Gender \& Society, 6, 609-622.

Bellas, M. L. (1994). Comparable worth in academia: The effects on faculty salaries of the sex composition and labor-market conditions of academic disciplines. American Sociological Review, 59, 807-821.

Bellas, M. L. (1997a). Disciplinary differences in faculty salaries: Does gender bias play a role? Journal of Higher Education, 68, 299-321.

Bellas, M.L. (1997b). The scholarly productivity of academic couples. In M. A. Ferber \& J. W. Loeb (Eds.), Academic couples: Problems and promises. Urbana: University of Illinois Press.

Bellas, M. L., \& Toutkoushian, R. K. (1999). Faculty time allocations and research productivity: Gender, race, and family effects. Review of Higher Education, 22, 367-390.

Bielby, D. D., \& Bielby, W. T. (1988). She works hard for the money: Household responsibilities and the allocation of work effort. American Journal of Sociology, 93, 1031-1059. 
Bond, J. T., Galinsky, E., \& Swanberg, J. E. (1997). The 1997 national study of the changing workforce. New York: Families and Work Institute.

Bowen, H. R., \& Schuster, J. H. (1986). American professors: A national resource imperiled. New York: Oxford University Press.

Bronstein, P., Rothblum, E. D., \& Solomon, S. E. (1993). Ivy halls and glass walls: Barriers to academic careers for women and ethnic minorities. In J. Gainen \& R. Boice (Eds.), Building a diverse faculty (Vol. 53, pp. 17-31). San Francisco: Jossey-Bass Publishers.

Chronister, J. L., Baldwin, R. G., \& Bailey, T. (1996). Full-time non-tenure track faculty: Current status, condition, and attitudes. In D. E. Finnegan, D. Webster, \& Z. F. Gamson (Eds.), Faculty and faculty issues in colleges and universities (2nd ed., pp. 326-336). Needham Heights, MA: Simon \& Schuster Custom Publishing, ASHE Reader Series.

Chronister, J. L., Gansneder, B. M., Harper, E., \& Baldwin, R. G. (1997). Full-time nontenure track faculty. NEA Higher Education Research Center Update, 3(5), 1-4.

Cole, J. R., \& Zuckerman, H. (1987). Marriage, motherhood, and research performance in science. Scientific American, 256(2), 119-125.

Cooney, T. M., \& Uhlenberg, P. (1989). Family-building patterns of professional women: A comparison of lawyers, physicians, and postsecondary teachers. Journal of Marriage and the Family, 51, 749-758.

Creamer, E. G. (1998). Assessing faculty publication productivity: Issues of equity. (ASHE-ERIC Higher Education Report Vol. 26, No. 2). Washington, DC: The George Washington University: Graduate School of Education and Human Development.

Dey, E. L. (1994). Dimensions of faculty stress: A recent survey. Review of Higher Education, 17, 305-322.

DeYoung, A. J. (1989). Economics and American education: A historical and critical overview of the impact of economic theories on schooling in the United States. White Plains, NY: Longman Inc.

Dreijmanis, J. (1991). Higher education and employment: Is professional employment a right? Higher Education Review, 23(3), 7-18.

England, P. (1982). The failure of human capital theory to explain occupational sex segregation. Journal of Human Resources, 17, 358-370.

Ferber, M. A., \& Hoffman, E. P. (1997). Are academic partners at a disadvantage? In M. A. Ferber \& J. W. Loeb (Eds.), Academic couples: Problems and promises. Urbana: University of Illinois Press.

Finkel, S. K., Olswang, S., \& She, N. (1994). Childbirth, tenure, and promotion for women faculty. Review of Higher Education, 17, 259-270.

Flynn, E. A., Flynn, J. F., Grimm, N., \& Lockhart, T. (1986). The part-time problem: Four voices. Academe, 72(1), 12-18.

Franklin, P., Laurence, D., \& Denham, R. D. (1988). When solutions become problems: Taking a stand on part-time employment. Academe, 74(3), 15-19.

Gappa, J., \& Leslie, D. (1993). The invisible faculty: Improving the status of part-timers in higher education. San Francisco: Jossey-Bass.

Hamovitch, W., \& Morgenstern, R. D. (1977). Children and the productivity of academic women. Journal of Higher Education, 48, 633-645.

Hough, J. R. (1987). Education and the national economy. New York: Croom Helm. 
Johnson, G. E., \& Stafford, F. P. (1974). The earnings and promotion of women faculty. American Economic Review, 64, 888-903.

Kasper, H., Bronner, F., Gray, M. W., Kreiser, B. R., \& Rosenthal, J. R. (1986). 1986 report on full-time non-tenure track appointments. Academe, 72(4), 14a-19a.

Kasten, K. L. (1984). Tenure and merit pay as rewards for research, teaching, and service at a research university. Journal of Higher Education, 55, 500-514.

Kirshstein, R. J., Matheson, N., \& Jing, Z. (1997). Instructional faculty and staff in higher education institutions: Fall 1987 and Fall 1992. Washington, DC: U.S. Department of Education, National Center for Education Statistics (NCES 97-447).

Korenman, S., \& Neumark, D. (1991). Marriage, motherhood, and wages. Journal of Human Resources, 27, 233-255.

Lomperis, A. M. T. (1990). Are women changing the nature of the academic profession? Journal of Higher Education, 61, 643-677.

Marshall, M. R., \& Jones, C. H. (1990). Childbearing sequence and the career development of women administrators in higher education. Journal of College Student Development, 31, 531-537.

Marwell, G., Rosenfeld, R., \& Spilerman, S. (1979). Geographic constraints on women's career in academia. Science, 205, 1225-1231.

McElrath, K. (1992). Gender, career disruption, and academic rewards. Journal of Higher Education, 63, 269-281.

Menard, S. (1995). Applied logistic regression analysis. Thousand Oaks: Sage.

Polachek, S. W. (1977). Occupational segregation among women: Theory, evidence, and a prognosis. In C. B. Lloyd, E. S. Andrews, \& C. L. Gilroy (Eds.), Women in the Labor Market. New York: Columbia University Press.

Raabe, P. H. (1997). Work-family policies for faculty: How "career- and familyfriendly" is academe? In M. A. Ferber \& J. W. Loeb (Eds.), Academic couples: Problems and Promises (pp. 208-225). Urbana: University of Illinois Press.

Rajagopal, I., \& Farr, W. D. (1992). Hidden academics: The part-time faculty in Canada. Higher Education, 24, 317-331.

Riemenschnieder, A., \& Harper, K. V. (1990). Women in academia: Guilty or not guilty? Conflict between caregiving and employment. Initiatives, 53(2), 27-35.

Rosenfeld, R. A., \& Jones, J. A. (1987). Patterns and effects of geographic mobility for academic women and men. Journal of Higher Education, 58, 493-515.

Smart, J. C. (1991). Gender equity in academic rank and salary. Review of Higher Education, 14, 511-526.

Smart, J. C., \& McLaughlin, G. W. (1978). Reward structures of academic disciplines. Research in Higher Education, 8, 39-55.

Sorcinelli, M. D., \& Near, J. P. (1989). Relations between work and life away from work among university faculty. Journal of Higher Education, 60, 59-81.

Sorenson, E. (1989). Measuring the effect of occupational sex and race composition on earnings. In R. T. Michael, H. I. Hartmann, \& B. O'Farrell (Eds.), Pay equity: Empirical inquiries (chap. 2). Washington, DC: National Academy Press.

Tack, M. W., \& Patitu, C. L. (1992). Faculty job satisfaction: Women and minorities in peril. (ASHE-ERIC Higher Education Report No. 4). Washington, DC: The George Washington University, School of Education and Human Development. 
Toutkoushian, R. K. (1998). Racial and marital status differences in faculty pay. Journal of Higher Education, 69, 513-541.

Wilson, R. (1998, July). For some adjunct faculty members, the tenure track holds little appeal. Chronicle of Higher Education, pp. A9-A10.

Youn, T. I. K. (1988). Studies of academic markets and careers: An historical review. In D. W. Breneman, \& T. I. K. Youn (Eds.), Academic labor markets and careers (chap. 1, pp. 8-27). New York: The Falmer Press.

Youn, T. I. K. (1992). The sociology of academic careers and academic labor markets. Research in Labor Markets, 13, 101-130. 